\title{
Intradermal versus Intramuscular Administration of Influenza Vaccination: Rapid Review and Meta-analysis
}

Oluwaseun Egunsola $\mathrm{PhD}^{1}$, Fiona Clement $\mathrm{PhD}^{1}$, John Taplin $\mathrm{BSc}^{1}$, Liza Mastikhina $\mathrm{MSc}^{1}$, Joyce W. Li BSc${ }^{1}$, Diane L. Lorenzetti PhD ${ }^{1,2}$, Laura E. Dowsett MSc ${ }^{1}$, Tom Noseworthy $\mathrm{MD}^{1}$

\section{Affiliations}

1. The Department Community Health Sciences, University of Calgary. Teaching Research and Wellness Building 3280 Hospital Drive NW Calgary Alberta T2N 4N1 2. Health Sciences Library, University of Calgary

Acknowledgements: We thank Andrea Tricco and the Drug Safety and Effectiveness Network (DSEN) Methods and Applications Group for Indirect Comparisons (MAGIC) team.

Contributors: TN, LED, FC, DL conceptualized the study. OE, LED, LM, JL, JT, DL acquired the data. OE analyzed the data. OE, LED, LM, JL, JT, DL drafted the article, FC and TN revised the article for critically important intellectual content. All authors approved the final version of the article.

Funding Statement: This Project was supported with funding from the Canadian Institutes of Health Research (CIHR) under the Drug Safety and Effectiveness Network initiative. The funders did not have any role in the design and conduct of the study; collection, management, analysis, and interpretation of the data; preparation, review, or approval of the manuscript; and decision to submit the manuscript for publication.

Copyright claims/Disclaimers: The intellectual property rights in data and results generated from the work reported in this document are held in joint ownership between the MAGIC team and the named Contributors. Users are permitted to disseminate the data and results presented in this report provided that the dissemination (i) does not misrepresent the data, results, analyses or conclusions, and (ii) is consistent with academic practice, the rights of any third party publisher, and applicable laws. Any dissemination of the data and results from this document shall properly acknowledge the MAGIC team and named Contributors.

For questions about this report, please contact:

Dr. Fiona Clement

Director, Health Technology Assessment Unit, University of Calgary

Email: fclement@ucalgary.ca

Phone: 403-210-9373 
medRxiv preprint doi: https://doi.org/10.1101/2020.10.06.20205989; this version posted October 8, 2020. The copyright holder for this preprint (which was not certified by peer review) is the author/funder, who has granted medRxiv a license to display the preprint in perpetuity.

\begin{abstract}
Background: Vaccinations are essential for prevention of influenza. We synthesized the published literature on the immunogenicity and safety of the influenza vaccine at reduced or full intradermal doses compared with full intramuscular doses.
\end{abstract}

Methods: A rapid review of the literature was completed. MEDLINE, EMBASE, and the Cochrane Central Register of Controlled Trials were searched for studies published from 2010 until June $5^{\text {th }}$, 2020. All studies comparing intradermal and intramuscular influenza vaccinations were included. Random-effects meta-analyses of immunogenicity and safety outcomes were conducted.

Results: A total of 30 relevant studies were included. Seroconversion rates were equivalent between the $3 \mathrm{mcg}, 6 \mathrm{mcg}, 7.5 \mathrm{mcg}$, and $9 \mathrm{mcg}$ intradermal vaccine doses and the $15 \mathrm{mcg}$ intramuscular vaccine dose for each of the H1N1, H3N2, and B strains, but significantly higher with the $15 \mathrm{mcg}$ intradermal compared with the $15 \mathrm{mcg}$ intramuscular dose, for the H1N1 (RR 1.10, 95\% Cl: 1.01-1.20) and B strains (RR 1.40, 95\% Cl: 1.13-1.73). Seroprotection rates for the $9 \mathrm{mcg}$ and $15 \mathrm{mcg}$ intradermal doses were equivalent with the 15 mcg intramuscular dose for all the three strains, except for the $15 \mathrm{mcg}$ intradermal dose for the H1N1 strain which was significantly higher (RR 1.05, 95\% Cl: 1.01-1.09). Local adverse events were significantly higher with intradermal doses. Fever and chills were significantly higher with the 9 mcg intradermal dose, while all other systemic adverse events were equivalent for all doses.

Conclusion: Reduced dose intradermal influenza vaccination appears to be a reasonable alternative to standard dose intramuscular vaccination because of the similarity in immunogenicity. 
medRxiv preprint doi: https://doi.org/10.1101/2020.10.06.20205989; this version posted October 8, 2020. The copyright holder for this preprint (which was not certified by peer review) is the author/funder, who has granted medRxiv a license to display the preprint in perpetuity. It is made available under a CC-BY-ND 4.0 International license .

\section{Background}

Influenza infection causes three-to-five million severe illnesses and approximately half a million annual deaths globally. ${ }^{1}$ It is a highly contagious disease characterized by high fever, cough, sore throat, headache, chills, lack of appetite, and fatigue. ${ }^{2}$ Vaccinations are essential for prevention of influenza and can be administered intradermally or intramuscularly, with the latter being the more common method. ${ }^{3}$

The interest in intradermal vaccines has been increasing as a solution to mitigate potential vaccine shortages, which could occur from unanticipated loss of expected supplies or from excessive demand due to high rates of infection, such as during pandemics. ${ }^{4}$ With the approval of new intradermal vaccines, ${ }^{256}$ new delivery devices, including mini-needles, microneedles, patches and disposable-syringe jet injectors, have become available. ${ }^{37}$

Intradermal vaccinations have a dose-sparing effect; ${ }^{3}$ therefore, smaller doses of intradermal vaccines may be sufficient to produce an antigenic response that is similar to standard intramuscular doses. The dermis is rich in dendritic cells, which are very potent antigen-presenting cells that elicit cell mediated immune responses, especially CD4+ and CD8+ T-cell responses which are essential in the immune response to influenza viruses. ${ }^{48}$ Intramuscular injection bypasses this immune system response and delivers the vaccine directly into the muscular tissue, which has relatively few resident antigen-presenting cells. ${ }^{9}$ Previous studies have compared the immunogenicity (ability of the vaccine to evoke an immune response) and safety of intradermal and intramuscular influenza vaccines; however, the magnitude of the effect has not yet been examined. In this study, we synthesized the published literature on the immunogenicity and safety of the influenza vaccine at reduced or regular intradermal doses compared with a full intramuscular dose.

\section{Methods}

\subsection{Literature Search}

A rapid review of the literature was completed. MEDLINE, EMBASE, and the Cochrane Central Register of Controlled Trials were searched for studies published from inception until June $5^{\text {th }}, 2020$. Terms aimed to capture the technology of interest, such as "intradermal," "ID injection" and "mantoux" were combined using the Boolean Operator "and" with influenza terms. These terms were searched as text words in titles and key word headings and as MeSH subject headings when applicable. The search excluded case reports, editorials, letters, and animal studies. The search strategy was developed by a research librarian, and PRESS-reviewed by another research librarian. ${ }^{10}$ This 
medRxiv preprint doi: https://doi.org/10.1101/2020.10.06.20205989; this version posted October 8, 2020. The copyright holder for this preprint (which was not certified by peer review) is the author/funder, who has granted medRxiv a license to display the preprint in perpetuity.

It is made available under a CC-BY-ND 4.0 International license .

search was supplemented by scrutinizing the reference lists of systematic literature reviews to ensure that all studies meeting the inclusion criteria were captured.

\subsection{Literature Selection}

Abstracts identified through database searching were screened by a single reviewer; all abstracts included at this stage proceeded to full-text review. Full-text publications were screened by a single reviewer. Publications were included if they met all inclusion criteria and failed to meet any exclusion criteria outlined in Table 1.

Table 1. Inclusion and Exclusion Criteria

\begin{tabular}{|c|c|}
\hline Inclusion Criteria & Exclusion Criteria \\
\hline $\begin{array}{l}\text { - All ages, humans only } \\
\text { Must compare intradermal } \\
\text { administration of the inactivated } \\
\text { influenza vaccine (trivalent standard- } \\
\text { dose influenza vaccine, quadrivalent } \\
\text { standard-dose influenza vaccine, } \\
\text { adjuvanted trivalent influenza vaccine, } \\
\text { high-dose trivalent influenza vaccine) } \\
\text { with intramuscular administration of the } \\
\text { influenza vaccine } \\
\text { Includes one of the following: } \\
\circ \quad \text { lab-confirmed influenza } \\
\quad \text { infection } \\
\circ \quad \text { influenza-like illness } \\
\circ \quad \text { hospitalization } \\
\circ \quad \text { ICU admission } \\
\circ \quad \text { pneumonia } \\
\circ \quad \text { mortality } \\
\circ \quad \text { immunogenicity } \\
\circ \quad \text { adverse events } \\
\text { Randomized controlled trials (RCTs), } \\
\text { NRCTs (e.g., such as quasi-RCTs, } \\
\text { non-randomized trials, interrupted time } \\
\text { series, controlled before after), and } \\
\text { observational studies (e.g., cohort, } \\
\text { case control) } \\
\text { Published 2010-2020 }\end{array}$ & $\begin{array}{ll} & \text { Animal models } \\
\text { - } & \text { Non-influenza vaccination } \\
\text { - } & \text { Inclusion of immune compromised } \\
\text { - } & \text { patients } \\
\text { ctudy designs without a control or } \\
\text { comparator such as: cross-sectional, } \\
\text { case series, case reports, and } \\
\text { qualitative studies. } \\
\text { Commentaries, conference } \\
\text { proceedings }\end{array}$ \\
\hline
\end{tabular}

\subsection{Data Extraction}

For all included studies, year of publication, country, study design, dates of recruitment, study inclusion and exclusion criteria, setting, patient characteristics, treatment protocol (e.g., intention-to-treat, per-protocol), sample size, follow-up time, geometric mean titer (GMT), defined as the antilog of the arithmetic mean of the log-transformed titers, seroconversion and seroprotection rates and all relevant outcomes were extracted by a single reviewer and verified by a second reviewer using standardized data extraction 
medRxiv preprint doi: https://doi.org/10.1101/2020.10.06.20205989; this version posted October 8, 2020. The copyright holder for this preprint (which was not certified by peer review) is the author/funder, who has granted medRxiv a license to display the preprint in perpetuity.

forms. Discrepancies between reviewers during data extraction were resolved through consensus.

\subsection{Quality Assessment}

The quality of randomized controlled trials were assessed using the Cochrane Handbook Risk of Bias Assessment Tool (version 5.1.0). ${ }^{11}$ Each study was assessed using seven criteria broadly covering the areas of randomization, allocation concealment, blinding of participants and personnel, blinding of outcome assessment, incomplete outcome data, and selective reporting. Each criterion was assigned a rating of "low," "high," or "unclear."

The quality of cohort studies was assessed using the Newcastle Ottawa Scale. Each study was assessed across three categories: selection, comparability, and outcome. Items within selection and comparability were assigned up to one 'star' for high quality, while items within comparability were assigned a maximum of two 'stars.'

Quality assessment was completed by a single reviewer and verified by a second reviewer. Discrepancies were resolved through discussion. Studies were not excluded based on quality assessment.

\subsection{Data Analysis}

Random-effects meta-analysis was conducted, utilizing the DerSimonian and Laird estimator $^{12}$ for Tau. Statistical heterogeneity was assessed using the $1^{2}$ measure, with values above or below $50 \%$ considered high and low heterogeneity respectively. A continuity correction of 0.5 was used where appropriate, allowing the inclusion of zerototal event trials. ${ }^{13}$ Stratified analyses by dose were completed for the geometric mean titer, seroconversion, seroprotection, and adverse events. Only immunogenicity outcomes for days 21-30 post-vaccination were analyzed. Subgroup analyses of immunogenicity outcomes were conducted for studies involving participants $\geq 60$ years of age. Risk ratios were calculated for categorical outcomes and the ratio of geometric means calculated for GMT, as described by Friedrich el al. ${ }^{14}$ Publication bias for small studies with missing small effect sizes was assessed using Egger's test ${ }^{15}$ when the number of studies was greater than four, and, where appropriate, the Duval \& Tweedie's trim-and-fill method ${ }^{16}$ was used to adjust for funnel plot asymmetry. All analyses were completed in $\mathrm{R}$ version 3.6.1.

\section{Results}

\subsection{Study Characteristics}

The search strategy yielded 914 unique citations; 869 were excluded after deduplication and abstract review. Forty-five studies proceeded to full-text review (Figure 1). Fifteen studies were excluded for the following reasons: study design $(n=5)$; incorrect outcome 
medRxiv preprint doi: https://doi.org/10.1101/2020.10.06.20205989; this version posted October 8, 2020. The copyright holder for this preprint (which was not certified by peer review) is the author/funder, who has granted medRxiv a license to display the preprint in perpetuity.

It is made available under a CC-BY-ND 4.0 International license .

$(n=5)$; duplicate $(n=2)$; incorrect study population $(n=1)$; and publication year not of interest $(n=1)$. A total of 30 relevant studies were included in the final dataset (Figure 1).

Twenty-nine of the studies were randomized controlled trials involving a total of 13,759 participants, ${ }^{17-45}$ and one study was a cohort study of 164,021 participants. ${ }^{46}$ All studies were published between 2010 and 2019. Sixteen studies were multi-centre, ${ }^{17-19} 21222830$ 323336374042434612 were single-centre, ${ }^{23-27} 29313435383944$ and two studies did not report the setting. ${ }^{2041}$ Half of the studies involved only participants $\geq 60$ years old or reported data for participants $\geq 60$ years old. ${ }^{1718202123-2628334042434546}$

Figure 1. PRISMA Flowchart of Included and Excluded Studies
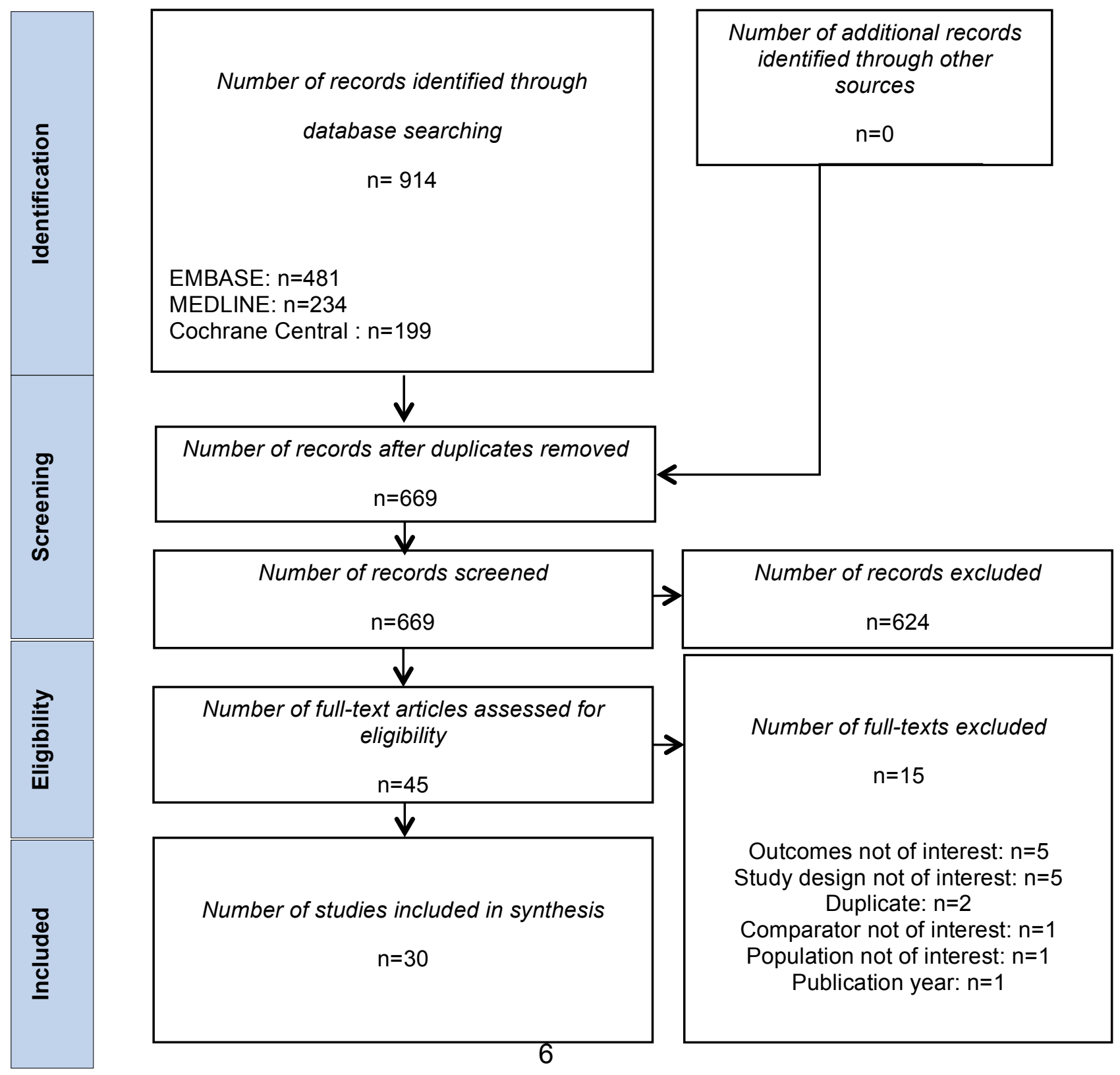
medRxiv preprint doi: https://doi.org/10.1101/2020.10.06.20205989; this version posted October 8, 2020. The copyright holder for this preprint (which was not certified by peer review) is the author/funder, who has granted medRxiv a license to display the preprint in perpetuity.

\subsection{Quality Assessment}

The majority of the studies had some bias stemming from the randomization process; six studies were at low risk of bias; ${ }^{1922} 23293134$ and two studies were at high risk. ${ }^{2733}$ All but two low risk studies ${ }^{22}{ }^{34}$ had some risk of bias due to deviations from intended interventions. All the included studies had low risk of bias due to missing outcome data. All but one high risk study ${ }^{33}$ were of low risk of bias stemming from the measurement of outcomes. Lastly, all the studies were of some concern of bias regarding selection of the reported results. Overall, all the studies except two high risk studies, ${ }^{27}{ }^{33}$ were of some concern for bias.

The only included cohort study was allocated nine stars. ${ }^{46}$ It was judged to be representative of the exposed population. Exposure and outcomes were ascertained from secure records and record linkage respectively. The cohorts were comparable and follow-up was long and adequate.

\subsection{Meta-analysis}

\subsubsection{Seroconversion}

Seroconversion rates were equivalent between the $3 \mathrm{mcg}, 6 \mathrm{mcg}, 7.5 \mathrm{mcg}$, and $9 \mathrm{mcg}$ intradermal vaccine doses and the $15 \mathrm{mcg}$ intramuscular vaccine dose for each of the $\mathrm{H} 1 \mathrm{~N} 1, \mathrm{H} 3 \mathrm{~N} 2$, and B strains. Furthermore, seroconversion rate for the H3N2 strain was also equivalent between the $15 \mathrm{mcg}$ intradermal and $15 \mathrm{mcg}$ intramuscular doses, but significantly higher with the $15 \mathrm{mcg}$ intradermal compared with $15 \mathrm{mcg}$ intramuscular dose, for the H1N1 (RR 1.10, 95\% Cl: 1.01-1.20) and B strains (RR 1.40, 95\% Cl: 1.131.73) (Table 2).

\subsubsection{Seroprotection}

Seroprotection rates were significantly lower with the $6 \mathrm{mcg}$ intradermal dose for the H1N1 (RR 0.93, 95\% Cl: 0.88-0.99) and the B strains (RR 0.92, 95\% Cl: 0.86-0.98). For the $9 \mathrm{mcg}$ intradermal doses, seroprotection rates were equivalent with the $15 \mathrm{mcg}$ intramuscular dose for all the three strains. The $15 \mathrm{mcg}$ intradermal and $15 \mathrm{mcg}$ intramuscular doses were also equivalent for $\mathrm{H} 3 \mathrm{~N} 2$ and $\mathrm{B}$ strains, however, seroprotection rate was significantly higher for the H1N1 strain (RR 1.05, 95\% Cl:1.011.09) (Table 2). 
Table 2. Seroconversion and Seroprotection of ID Doses versus Standard IM Dose

\begin{tabular}{|c|c|c|c|c|}
\hline & $\begin{array}{l}\text { ID Dose vs. } \\
15 \mathrm{mcg} \text { IM }\end{array}$ & $\begin{array}{l}\text { Number of } \\
\text { Studies }\end{array}$ & Risk Ratio [95\% Cl] & $1^{2}$ \\
\hline \multirow{5}{*}{$\begin{array}{l}\text { Seroconversion } \\
\text { H1N1 }\end{array}$} & $3 \mathrm{mcg}$ & 2 & $1.77[0.43-7.28]$ & 82.6 \\
\hline & $6 \mathrm{mcg}$ & 3 & $1.00[0.78-1.28]$ & 87.7 \\
\hline & $7.5 \mathrm{mcg}$ & 3 & $1.01[0.80-1.28]$ & 0 \\
\hline & $9 \mathrm{mcg}$ & 10 & $1.02[0.93-1.12]$ & 59 \\
\hline & $15 \mathrm{mcg}$ & 16 & $1.10[1.01-1.20]$ & 50.5 \\
\hline \multirow{5}{*}{$\begin{array}{l}\text { Seroconversion } \\
\text { H3N2 }\end{array}$} & $3 \mathrm{mcg}$ & 2 & $1.14[0.56-2.31]$ & 81.3 \\
\hline & $6 \mathrm{mcg}$ & 3 & $0.98[0.97-1.00]$ & 0 \\
\hline & $7.5 \mathrm{mcg}$ & 3 & $0.92[0.63-1.33]$ & 63.8 \\
\hline & $9 \mathrm{mcg}$ & 11 & $1.01[0.95-1.06]$ & 38 \\
\hline & $15 \mathrm{mcg}$ & 17 & $1.07[0.99-1.17]$ & 43.2 \\
\hline \multirow{5}{*}{$\begin{array}{l}\text { Seroconversion } \\
\text { B Strain }\end{array}$} & $3 \mathrm{mcg}$ & 2 & $1.46[0.67-1.99]$ & 53.5 \\
\hline & $6 \mathrm{mcg}$ & 3 & $0.95[0.68-1.32]$ & 88.3 \\
\hline & $7.5 \mathrm{mcg}$ & 3 & $1.21[0.79-1.85]$ & 43.9 \\
\hline & $9 \mathrm{mcg}$ & 11 & $0.95[0.84-1.08]$ & 57.1 \\
\hline & $15 \mathrm{mcg}$ & 16 & $1.40[1.13-1.73]$ & 59.1 \\
\hline \multirow{5}{*}{$\begin{array}{l}\text { Seroprotection } \\
\text { H1N1 }\end{array}$} & $3 \mathrm{mcg}$ & 3 & $1.00[0.78-1.28]$ & 87.7 \\
\hline & $6 \mathrm{mcg}$ & 3 & $0.93[0.88-0.99]$ & 37.5 \\
\hline & $7.5 \mathrm{mcg}$ & 3 & $1.07[1.01-1.12]$ & 0 \\
\hline & $9 \mathrm{mcg}$ & 12 & $1.00[0.98-1.03]$ & 33 \\
\hline & $15 \mathrm{mcg}$ & 17 & $1.05[1.01-1.09]$ & 43.6 \\
\hline \multirow{5}{*}{$\begin{array}{l}\text { Seroprotection } \\
\text { H3N2 }\end{array}$} & $3 \mathrm{mcg}$ & 3 & $0.98[0.97-1.00]$ & 0 \\
\hline & $6 \mathrm{mcg}$ & 3 & $1.00[0.99-1.01]$ & 0 \\
\hline & $7.5 \mathrm{mcg}$ & 3 & $1.01[0.96-1.06]$ & 36.6 \\
\hline & $9 \mathrm{mcg}$ & 12 & $1.00[0.99-1.00]$ & 0 \\
\hline & $15 \mathrm{mcg}$ & 18 & $1.01[0.99-1.02]$ & 25.9 \\
\hline \multirow{5}{*}{$\begin{array}{l}\text { Seroprotection } \\
\text { B Strain }\end{array}$} & $3 \mathrm{mcg}$ & 3 & $0.95[0.68-1.32]$ & 88.3 \\
\hline & $6 \mathrm{mcg}$ & 3 & $0.92[0.86-0.98]$ & 0 \\
\hline & $7.5 \mathrm{mcg}$ & 3 & $1.13[0.78-1.66]$ & 58.2 \\
\hline & $9 \mathrm{mcg}$ & 12 & $0.99[0.95-1.03]$ & 50 \\
\hline & $15 \mathrm{mcg}$ & 16 & $1.03[0.97-1.09]$ & 48.5 \\
\hline
\end{tabular}

Outcome significantly higher with ID administration

No significant difference in outcome between ID and IM administration

Outcome significantly lower with ID administration 


\subsubsection{Geometric Mean Titer}

The GMTs were equivalent between the $3 \mathrm{mcg}$ and $6 \mathrm{mcg}$ intradermal doses and the 15 mcg intramuscular dose for the three strains, except for a significant decrease for H1N1 observed with the $6 \mathrm{mcg}$ intradermal dose (RR 0.88, 95\% Cl: 0.85-0.90). Similarly, GMTs were equivalent for the $\mathrm{H} 1 \mathrm{~N} 1$ and $\mathrm{B}$ strains when the $9 \mathrm{mcg}$ intradermal dose was compared with the $15 \mathrm{mcg}$ intramuscular dose, but significantly higher for the H3N2 strain (RR 1.08, 95\% Cl: 1.05-1.12). The $15 \mathrm{mcg}$ intradermal dose showed equivalence with the $15 \mathrm{mcg}$ intramuscular dose for the H1N1 and the H3N2 strains. However, the $15 \mathrm{mcg}$ intradermal dose was associated with significantly higher GMT for the B strain (RR 1.21, 95\% Cl: 1.11-1.32) (Table 3).

Table 3. Geometric Mean Titer of ID Doses versus Standard IM Dose

\begin{tabular}{|l|c|c|c|c|}
\cline { 2 - 5 } \multicolumn{1}{c|}{} & $\begin{array}{c}\text { ID Dose vs. } \\
\mathbf{1 5 m c g} \text { IM }\end{array}$ & $\begin{array}{c}\text { Number of } \\
\text { Studies } \\
\text { Pooled }\end{array}$ & Ratio of Means [95\% CI] & $\mathbf{I}^{\mathbf{2}}$ \\
\hline \multirow{4}{*}{ GMT H1N1 } & $3 \mathrm{mcg}$ & 3 & $1.00[0.54-1.84]$ & 99.9 \\
\cline { 2 - 5 } & $6 \mathrm{mcg}$ & 2 & $0.88[0.85-0.90]$ & 65.1 \\
\cline { 2 - 5 } & $9 \mathrm{mcg}$ & 11 & $1.04[0.99-1.10]$ & 99.8 \\
\hline \multirow{4}{*}{ GMT H3N2 } & $15 \mathrm{mcg}$ & 11 & $1.17[0.95-1.42]$ & 99.9 \\
\cline { 2 - 5 } & $3 \mathrm{mcg}$ & 3 & $0.90[0.68-1.18]$ & 99.4 \\
\cline { 2 - 5 } & $6 \mathrm{mcg}$ & 3 & $1.09[0.90-1.32]$ & 99 \\
\cline { 2 - 5 } & $9 \mathrm{mcg}$ & 11 & $1.08[1.05-1.12]$ & 99.4 \\
\hline GMT B strain & $15 \mathrm{mcg}$ & 11 & $1.16[0.96-1.41]$ & 100 \\
\cline { 2 - 5 } & $3 \mathrm{mcg}$ & 3 & $0.80[0.46-1.38]$ & 99.9 \\
\cline { 2 - 5 } & $6 \mathrm{mcg}$ & 2 & $0.82[0.67-1.01]$ & 98.9 \\
\cline { 2 - 5 } & $9 \mathrm{mcg}$ & 11 & $0.93[0.86-1.01]$ & 99.9 \\
\cline { 2 - 5 } & $15 \mathrm{mcg}$ & 11 & $1.21[1.11-1.32]$ & 99.8 \\
\hline
\end{tabular}

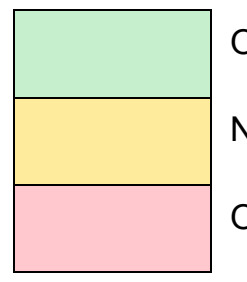

Outcome significantly higher with ID administration

No significant difference in outcome between ID and IM administration

Outcome significantly lower with ID administration 


\subsubsection{Immunogenicity in the Elderly}

Subgroup analyses for immunogenicity in the elderly (aged 60 years and older) showed equivalence between the $9 \mathrm{mcg}$ intradermal and $15 \mathrm{mcg}$ intramuscular doses, with respect to seroconversion, seroprotection, and GMT for each of the three strains. Seroprotection rates were also equivalent between the $15 \mathrm{mcg}$ intradermal and intramuscular doses for the three strains, while seroconversion rate and GMT were significantly higher with the $15 \mathrm{mcg}$ intradermal dose compared with the $15 \mathrm{mcg}$ intramuscular dose for the B strain (RR 1.41, 95\% Cl: 1.13- 1.75 and $R R 1.19,95 \% \mathrm{Cl}$ : 1.09-1.30, respectively) (Table 4).

Table 4. Immunogenicity of ID Doses versus Standard IM Dose among Participants $\geq 60$ Years

\begin{tabular}{|c|c|c|c|c|}
\hline & $\begin{array}{l}\text { ID Dose vs. } \\
\text { 15mcg IM }\end{array}$ & $\begin{array}{l}\text { Number of } \\
\text { Studies } \\
\text { Pooled }\end{array}$ & $\begin{array}{c}\text { Risk Ratio/*RoM }[95 \% \\
\mathrm{Cl}]\end{array}$ & $I^{2}$ \\
\hline \multirow{2}{*}{$\begin{array}{l}\text { Seroconversion } \\
\text { H1N1 }\end{array}$} & $9 \mathrm{mcg}$ & 2 & $1.01[0.58-1.77]$ & 87 \\
\hline & $15 \mathrm{mcg}$ & 13 & $1.11[1.00-1.24]]$ & 57.3 \\
\hline \multirow{2}{*}{$\begin{array}{l}\text { Seroconversion } \\
\text { H3N2 }\end{array}$} & $9 \mathrm{mcg}$ & 2 & $1.02[0.83-1.25]$ & 0 \\
\hline & $15 \mathrm{mcg}$ & 14 & $1.12[1.00-1.25]$ & 52.1 \\
\hline \multirow{2}{*}{$\begin{array}{l}\text { Seroconversion B } \\
\text { strain }\end{array}$} & $9 \mathrm{mcg}$ & 2 & $1.00[0.60-1.67]$ & 0 \\
\hline & $15 \mathrm{mcg}$ & 13 & $1.41[1.13-1.75]$ & 59 \\
\hline \multirow{2}{*}{ Seroprotection H1N1 } & $9 \mathrm{mcg}$ & 4 & $0.98[0.88-1.09]$ & 24.1 \\
\hline & $15 \mathrm{mcg}$ & 14 & $1.04[1.00-1.09]$ & 55.1 \\
\hline \multirow{2}{*}{ Seroprotection H3N2 } & $9 \mathrm{mcg}$ & 4 & $1.03[0.94-1.12]$ & 0 \\
\hline & $15 \mathrm{mcg}$ & 11 & $1.01[0.99-1.03]$ & 38.6 \\
\hline \multirow{2}{*}{$\begin{array}{l}\text { Seroprotection B } \\
\text { strain }\end{array}$} & $9 \mathrm{mcg}$ & 4 & $0.95[0.71-1.27]$ & 0 \\
\hline & $15 \mathrm{mcg}$ & 12 & $1.03[0.97-1.09]$ & 45.3 \\
\hline \multirow{2}{*}{ GMT H1N1 } & $9 \mathrm{mcg}$ & 4 & $0.96[0.75-1.23]$ & 99.3 \\
\hline & $15 \mathrm{mcg}$ & 11 & $1.11[0.89-1.39]$ & 100 \\
\hline \multirow{2}{*}{ GMT H3N2 } & $9 \mathrm{mcg}$ & 4 & $1.07[0.80-1.44]$ & 99.5 \\
\hline & $15 \mathrm{mcg}$ & 7 & $1.13[0.92-1.40]$ & 100 \\
\hline \multirow{2}{*}{ GMT B strain } & $9 \mathrm{mcg}$ & 4 & $0.93[0.72-1.20]$ & 99.5 \\
\hline & $15 \mathrm{mcg}$ & 9 & $1.19[1.09-1.30]$ & 99.8 \\
\hline
\end{tabular}

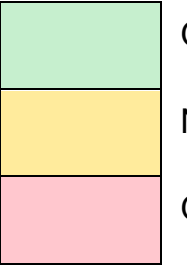

Outcome significantly higher with ID administration

No significant difference in outcome between ID and IM administration

Outcome significantly lower with ID administration

${ }^{*}$ RoM for GMT
} 
medRxiv preprint doi: https://doi.org/10.1101/2020.10.06.20205989; this version posted October 8, 2020. The copyright holder for this preprint (which was not certified by peer review) is the author/funder, who has granted medRxiv a license to display the preprint in perpetuity.

It is made available under a CC-BY-ND 4.0 International license .

\subsubsection{Influenza Infection or Influenza-like Illness}

A meta-analysis of four studies reporting clinical outcomes showed that the risk of influenza or influenza-like illness was significantly lower with intradermal vaccines when compared to intramuscular vaccines (RR $0.62,95 \% \mathrm{Cl}$ : 0.49-0.77). There was, however, no significant difference between the two routes of administration after dose stratification (Figure 2).

Figure 2. Risk of Influenza and Influenza-like Illness by Route of Vaccine Administration

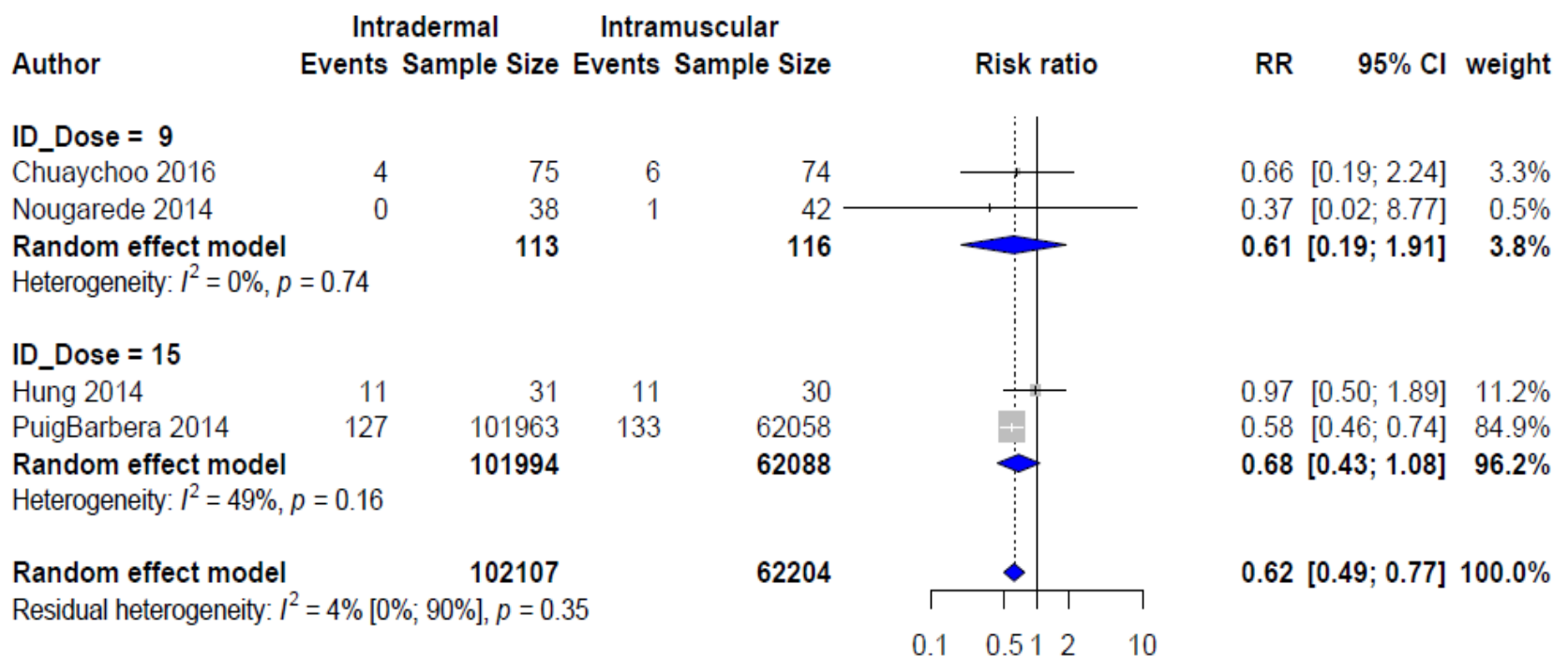

\subsubsection{Adverse Events}

Local adverse events, including erythema, swelling, induration, pruritus, and ecchymosis, were significantly higher across the dose spectrum of intradermal vaccines compared with the standard intramuscular dose. However, pain was equivalent between the $6 \mathrm{mcg}, 9 \mathrm{mcg}$, and $15 \mathrm{mcg}$ intradermal doses and the $15 \mathrm{mcg}$ intramuscular dose, but was significantly lower with the $3 \mathrm{mcg}$ intradermal dose (Table 5). Systemic adverse events, including headache, fever, malaise, arthralgia, myalgia, and nausea, were equivalent between the low intradermal doses and the standard intramuscular dose, albeit fever and chills were more common with the $9 \mathrm{mcg}$ intradermal dose (Table $6)$. 
Table 5. Local Adverse Events Risks with ID and IM Doses

\begin{tabular}{|c|c|c|c|c|}
\hline & $\begin{array}{l}\text { ID Dose vs } \\
15 \text { mcg IM }\end{array}$ & $\begin{array}{c}\text { Number of } \\
\text { Studies } \\
\text { Pooled }\end{array}$ & $\begin{array}{c}\text { Risk Ratio }[95 \% \\
\mathrm{Cl}]\end{array}$ & $1^{2}$ \\
\hline \multirow{2}{*}{ Ecchymosis } & $9 \mathrm{mcg}$ & 7 & $1.67[1.12-2.48]$ & 55 \\
\hline & $15 \mathrm{mcg}$ & 9 & $1.06[0.73-1.57]$ & 0 \\
\hline \multirow{4}{*}{ Erythema } & $3 \mathrm{mcg}$ & 3 & $9.62[1.07-86.56]$ & 97.2 \\
\hline & $6 \mathrm{mcg}$ & 2 & $23.79[14.42-39.23]$ & 0 \\
\hline & $9 \mathrm{mcg}$ & 14 & $4.56[3.05-6.82]$ & 93.9 \\
\hline & $15 \mathrm{mcg}$ & 16 & $3.68[3.19-4.25]$ & 8.8 \\
\hline \multirow{2}{*}{ Induration } & $9 \mathrm{mcg}$ & 5 & $3.27[1.65-6.46]$ & 95.4 \\
\hline & $15 \mathrm{mcg}$ & 9 & $2.98[2.32-3.84]$ & 42.6 \\
\hline \multirow{4}{*}{ Pain } & $3 \mathrm{mcg}$ & 4 & $0.34[0.20-0.56]$ & 21.9 \\
\hline & $6 \mathrm{mcg}$ & 2 & $0.98[0.38-2.49]$ & 68.3 \\
\hline & $9 \mathrm{mcg}$ & 12 & $0.95[0.86-1.05]$ & 34.4 \\
\hline & $15 \mathrm{mcg}$ & 16 & $0.94[0.72-1.21]$ & 61.3 \\
\hline \multirow{3}{*}{ Pruritus } & $6 \mathrm{mcg}$ & 2 & $15.22[4.77-48.54]$ & 0 \\
\hline & $9 \mathrm{mcg}$ & 9 & $4.24[3.16-5.70]$ & 56.2 \\
\hline & $15 \mathrm{mcg}$ & 6 & $4.01[3.13-5.15]$ & 0 \\
\hline \multirow{3}{*}{ Swelling } & $3 \mathrm{mcg}$ & 2 & $20.16[4.68-86.82]$ & 51.3 \\
\hline & $9 \mathrm{mcg}$ & 13 & $5.23[3.58-7.62]$ & 84.4 \\
\hline & $15 \mathrm{mcg}$ & 12 & $3.47[2.21-5.45]$ & 71.9 \\
\hline
\end{tabular}

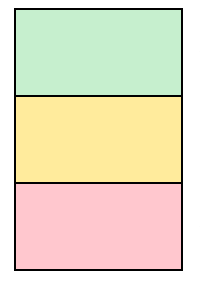

AE significantly lower with ID administration

No significant difference between ID and IM

AE significantly higher with ID administration 
Table 6. Systemic Adverse Events Risks with ID and IM Doses

\begin{tabular}{|c|c|c|c|c|}
\hline & $\begin{array}{c}\text { ID Dose vs } 15 \\
\text { mcg IM }\end{array}$ & $\begin{array}{c}\text { Number of } \\
\text { Studies Pooled }\end{array}$ & $\begin{array}{c}\text { Risk Ratio } \\
{[95 \% \mathrm{Cl}]}\end{array}$ & $\mathbf{I}^{2}$ \\
\hline Arthralgia & $15 \mathrm{mcg}$ & 3 & $1.17[0.39-3.53]$ & 22.7 \\
\hline \multirow{2}{*}{ Chills and shivering } & $9 \mathrm{mcg}$ & 7 & $1.24[1.03-1.50]$ & 0 \\
\hline & $15 \mathrm{mcg}$ & 10 & $1.08[0.78-1.51]$ & 0 \\
\hline \multirow{3}{*}{ Fever } & $6 \mathrm{mcg}$ & 2 & $0.54[0.17-1.71]$ & 34.5 \\
\hline & $9 \mathrm{mcg}$ & 11 & $1.36[1.03-1.80]$ & 0 \\
\hline & $15 \mathrm{mcg}$ & 13 & $0.89[0.59-1.34]$ & 0 \\
\hline \multirow{4}{*}{ Headache } & $3 \mathrm{mcg}$ & 2 & $1.09[0.86-1.37]$ & 0 \\
\hline & $6 \mathrm{mcg}$ & 2 & $0.83[0.39-1.78]$ & 68 \\
\hline & $9 \mathrm{mcg}$ & 13 & $1.03[0.96-1.11]$ & 0 \\
\hline & $15 \mathrm{mcg}$ & 9 & $1.16[0.94-1.45]$ & 0 \\
\hline \multirow{2}{*}{ Malaise } & $9 \mathrm{mcg}$ & 7 & $1.05[0.94-1.20]$ & 7.1 \\
\hline & $15 \mathrm{mcg}$ & 14 & $0.97[0.78-1.22]$ & 0 \\
\hline \multirow{2}{*}{ Myalgia } & $9 \mathrm{mcg}$ & 12 & $1.24[0.93-1.65]$ & 74.8 \\
\hline & $15 \mathrm{mcg}$ & 9 & $0.84[0.63-1.12]$ & 29.4 \\
\hline \multirow{2}{*}{ Nausea } & $9 \mathrm{mcg}$ & 3 & $0.93[0.37-2.31]$ & 0 \\
\hline & $15 \mathrm{mcg}$ & 2 & $1.05[0.33-3.33]$ & 0 \\
\hline
\end{tabular}

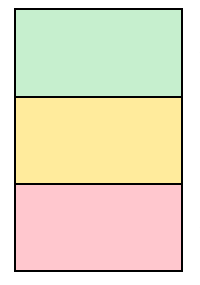

AE significantly lower with ID administration

No significant difference between ID and IM

AE significantly higher with ID administration

\subsubsection{Publication Bias}

Egger's test for publication bias was statistically significant for the $15 \mathrm{mcg}$ intradermal and intramuscular comparison for the $B$ and $\mathrm{H} 3 \mathrm{~N} 2$ strains seroconversion rates $(P=0.024$, respectively). Bias correction using trim and fill method did not change the statistical significance of the unadjusted results (Figure 3). 
medRxiv preprint doi: https://doi.org/10.1101/2020.10.06.20205989; this version posted October 8, 2020. The copyright holder for this preprint (which was not certified by peer review) is the author/funder, who has granted medRxiv a license to display the preprint in perpetuity.

Figure 3. Funnel Plot for Outcomes with Significant Asymmetry
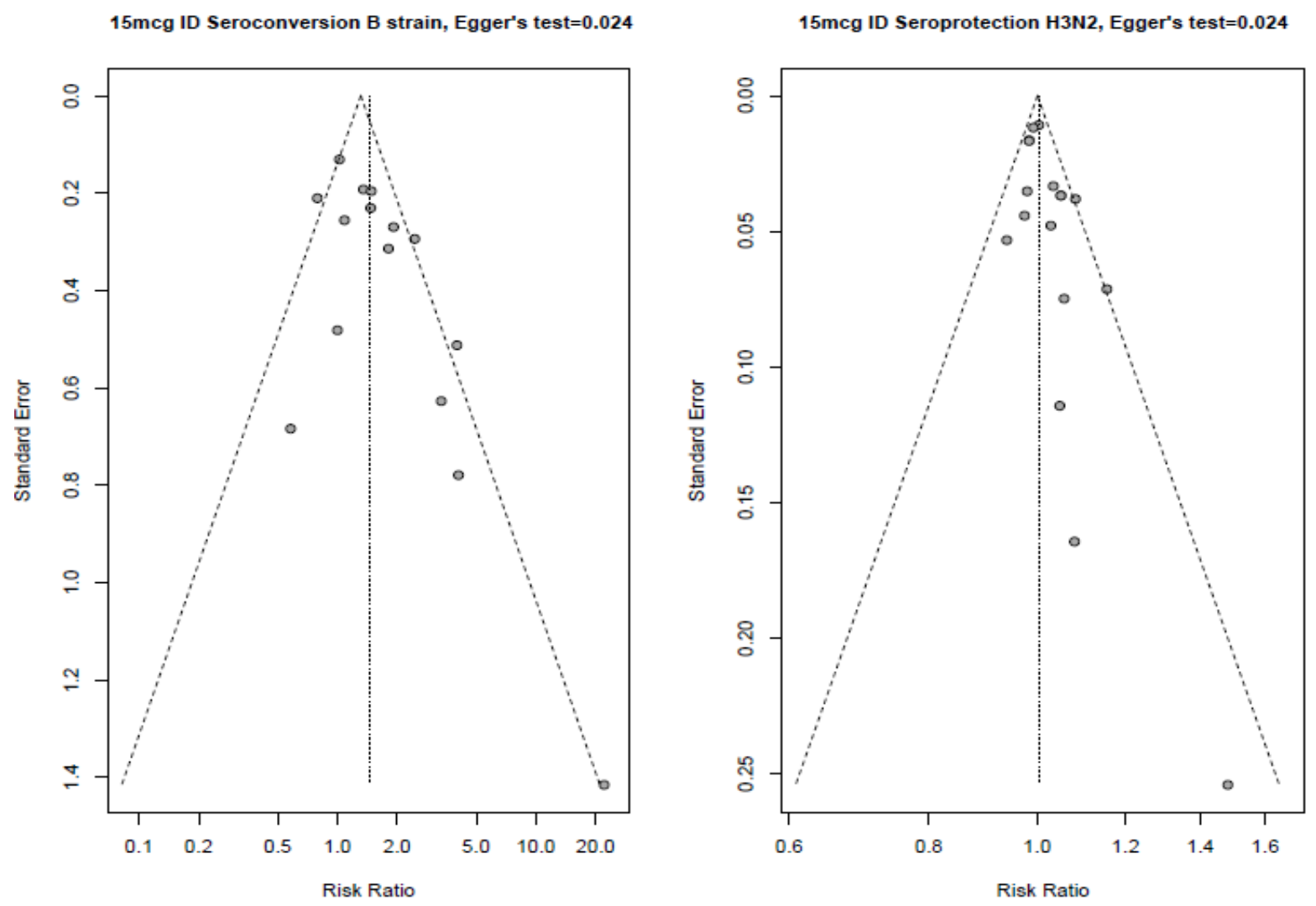

\section{Discussion}

This rapid review and meta-analysis showed that the $9 \mathrm{mcg}$ and $15 \mathrm{mcg}$ intradermal vaccination doses demonstrated immunogenicity that was equivalent to the full-dose 15 mcg intramuscular influenza vaccination, irrespective of patient age. However, the 15 mcg intradermal vaccine showed significantly better immunogenicity for some of the outcomes and strains, suggesting that the immunological response may be doserelated. The risk of local adverse events, such as erythema, induration, swelling, and ecchymosis was reduced with intramuscular vaccination; however, the risk of pain did not differ significantly between the two administration methods, with the exception of the $3 \mathrm{mcg}$ intradermal dose, which significantly lowered the risk of pain. The risks of systemic adverse events, such as headache, malaise, myalgia, and arthralgia, were similar with both administration methods.

The findings of the present study are similar to those by Marra et al. ${ }^{47}$ and Pileggi et al., ${ }^{48}$ which demonstrated equivalence between the different intradermal influenza vaccine doses and the $15 \mathrm{mcg}$ intramuscular influenza vaccine dose. It should be noted that Pileggi et al. included studies involving only immunocompromised participants in 
one of their studies ${ }^{48}$ and elderly participants in another. ${ }^{49}$ However, the present rapid review excluded immunocompromised patients and carried out sensitivity analysis of studies involving the elderly, given that old age ${ }^{50}$ and immunocompromise ${ }^{51}$ are known to attenuate immunological response. Although local skin reactions were more common with intradermal vaccinations, these reactions are generally well-accepted by vaccinees, ${ }^{52} 53$ who also find the microinjection systems to be more tolerable than the regular needles. ${ }^{53}$

A limitation of this study was the heterogeneity among the included studies, particularly with respect to the GMT outcome. This may be attributed to the variation in the characteristics of the study participants, including age and co-morbidities. However, heterogeneity persisted after stratifying the meta-analyses by age group. Other possible causes of heterogeneity include variations in vaccine factors, such as the use of adjuvants and differences in vaccine brands and delivery systems.

In conclusion, given the similarity in immunogenicity between the low dose intradermal and standard dose intramuscular influenza vaccine, low dose intradermal vaccine may be a reasonable alternative to standard dose intramuscular vaccination. 
medRxiv preprint doi: https://doi.org/10.1101/2020.10.06.20205989; this version posted October 8, 2020. The copyright holder for this preprint (which was not certified by peer review) is the author/funder, who has granted medRxiv a license to display the preprint in perpetuity.

It is made available under a CC-BY-ND 4.0 International license .

\section{References}

1. World Health Organization. Influenza (Seasonal) 2018 [Available from: https://www.who.int/en/news-room/fact-sheets/detail/influenza-(seasonal) accessed 12 July 2020.

2. Bragazzi NL, Orsi A, Ansaldi F, et al. Fluzone R intra-dermal (Intanza R/Istivac R Intradermal): An updated overview. Hum Vaccin Immunother 2016;12(10):2616-27. doi: https://dx.doi.org/10.1080/21645515.2016.1187343

3. Hickling J, Jones K, Friede M, et al. Intradermal delivery of vaccines: potential benefits and current challenges. Bulletin of the World Health Organization 2011;89:221-26.

4. La Montagne JR, Fauci AS. Intradermal influenza vaccination — can less be more?: Mass Medical Soc, 2004.

5. US Food and Drug Administration. 2020. https://www.fda.gov/media/139728/download (accessed 12 July 2020).

6. Center for infectious disease research and policy. Europe approves Sanofi's intradermal flu vaccine, 2009.

7. Levin Y, Kochba E, Hung I, et al. Intradermal vaccination using the novel microneedle device MicronJet600: Past, present, and future. Hum Vaccin Immunother 2015;11(4):991-97.

8. Steinman RM, Pope M. Exploiting dendritic cells to improve vaccine efficacy. The Journal of clinical investigation 2002;109(12):1519-26.

9. Romani N, Flacher V, Tripp C, et al. Targeting skin dendritic cells to improve intradermal vaccination. Intradermal Immunization: Springer 2011:113-38.

10. McGowan J, Sampson M, Salzwedel DM, et al. PRESS peer review of electronic search strategies: 2015 guideline statement. Journal of clinical epidemiology 2016;75:40-46.

11. The Cochrane Collaboration, Higgins J, Green S. Cochrane Handbook for Systematic Reviews of Inteventions: The Cochrane Collaboration's Tool for Assessing Risk of Bias. Cochrane Collaboration 2011

12. DerSimonian R, Laird N. Meta-analysis in clinical trials. Controlled clinical trials 1986;7(3):177-88.

13. Friedrich JO, Adhikari NK, Beyene J. Inclusion of zero total event trials in meta-analyses maintains analytic consistency and incorporates all available data. BMC medical research methodology 2007;7(1):1-6.

14. Friedrich JO, Adhikari NK, Beyene J. Ratio of geometric means to analyze continuous outcomes in meta-analysis: comparison to mean differences and ratio of arithmetic means using empiric data and simulation. Statistics in medicine 2012;31(17):1857-86.

15. Egger M, Smith GD, Schneider M, et al. Bias in meta-analysis detected by a simple, graphical test. Bmj 1997;315(7109):629-34.

16. Duval S, Tweedie R. Trim and fill: a simple funnel-plot-based method of testing and adjusting for publication bias in meta-analysis. Biometrics 2000;56(2):455-63.

17. Ansaldi F, Canepa P, Ceravolo A, et al. Intanza( R) $15 \mathrm{mcg}$ intradermal influenza vaccine elicits cross-reactive antibody responses against heterologous $\mathrm{A}(\mathrm{H} 3 \mathrm{~N} 2)$ influenza viruses. Vaccine 2012;30(18):2908-13. doi: https://dx.doi.org/10.1016/j.vaccine.2012.02.003 
medRxiv preprint doi: https://doi.org/10.1101/2020.10.06.20205989; this version posted October 8, 2020. The copyright holder for this preprint (which was not certified by peer review) is the author/funder, who has granted medRxiv a license to display the preprint in perpetuity. It is made available under a CC-BY-ND 4.0 International license .

18. Ansaldi F, Orsi A, de Florentiis D, et al. Head-to-head comparison of an intradermal and a virosome influenza vaccine in patients over the age of 60: evaluation of immunogenicity, cross-protection, safety and tolerability. Hum Vaccin Immunother 2013;9(3):591-8.

19. Arnou R, Eavis P, De Juanes Pardo JR, et al. Immunogenicity, large scale safety and lot consistency of an intradermal influenza vaccine in adults aged 18-60 years: Randomized, controlled, phase III trial. Hum 2010;6(4):346-54. doi:

http://dx.doi.org/10.4161/hv.6.4.10961

20. Boonnak K, Dhitavat J, Thantamnu N, et al. Immune responses to intradermal and intramuscular inactivated influenza vaccine among older age group. Vaccine 2017;35(52):7339-46. doi: https://dx.doi.org/10.1016/j.vaccine.2017.10.106

21. Camilloni B, Basileo M, Di Martino A, et al. Antibody responses to intradermal or intramuscular MF59-adjuvanted influenza vaccines as evaluated in elderly institutionalized volunteers during a season of partial mismatching between vaccine and circulating A(H3N2) strains. Immun Ageing 2014;11:10. doi: https://dx.doi.org/10.1186/1742-4933-11-10

22. Carter C, Houser KV, Yamshchikov GV, et al. Safety and immunogenicity of investigational seasonal influenza hemagglutinin DNA vaccine followed by trivalent inactivated vaccine administered intradermally or intramuscularly in healthy adults: An open-label randomized phase 1 clinical trial. PLOS ONE 2019;14(9) doi: http://dx.doi.org/10.1371/journal.pone.0222178

23. Chan TC, Hung IF, Chan KH, et al. Immunogenicity and safety of intradermal trivalent influenza vaccination in nursing home older adults: a randomized controlled trial. $J \mathrm{Am}$ Med Dir Assoc 2014;15(8):607.e5-12. doi: https://dx.doi.org/10.1016/j.jamda.2014.05.002

24. Chi RC, Rock MT, Neuzil KM. Immunogenicity and safety of intradermal influenza vaccination in healthy older adults. Clin Infect Dis 2010;50(10):1331-8. doi: https://dx.doi.org/10.1086/652144

25. Chuaychoo B, Kositanont U, Niyomthong P, et al. Comparison of immunogenicity between intradermal and intramuscular injections of repeated annual identical influenza virus strains post-pandemic (2011-2012) in COPD patients. Hum Vaccin Immunother 2019:19. doi: https://dx.doi.org/10.1080/21645515.2019.1692559

26. Chuaychoo B, Kositanont U, Rittayamai N, et al. The immunogenicity of the intradermal injection of seasonal trivalent influenza vaccine containing influenza A(H1N1)pdm09 in COPD patients soon after a pandemic. Hum Vaccin Immunother 2016;12(7):1728-37. doi: https://dx.doi.org/10.1080/21645515.2016.1149276

27. Chuaychoo B, Wongsurakiat $\mathrm{P}$, Nana A, et al. The immunogenicity of intradermal influenza vaccination in COPD patients. Vaccine 2010;28(24):4045-51. doi: https://dx.doi.org/10.1016/j.vaccine.2010.04.006

28. Della Cioppa G, Nicolay U, Lindert K, et al. A dose-ranging study in older adults to compare the safety and immunogenicity profiles of MF59 R-adjuvanted and non-adjuvanted seasonal influenza vaccines following intradermal and intramuscular administration. Hum Vaccin Immunother 2014;10(6):1701-10. doi: https://dx.doi.org/10.4161/hv.28618

29. Esposito S, Daleno C, Picciolli I, et al. Immunogenicity and safety of intradermal influenza vaccine in children. Vaccine 2011;29(44):7606-10. doi: https://dx.doi.org/10.1016/j.vaccine.2011.08.021 
medRxiv preprint doi: https://doi.org/10.1101/2020.10.06.20205989; this version posted October 8, 2020. The copyright holder for this preprint (which was not certified by peer review) is the author/funder, who has granted medRxiv a license to display the preprint in perpetuity. It is made available under a CC-BY-ND 4.0 International license .

30. Frenck RW, Jr., Belshe R, Brady RC, et al. Comparison of the immunogenicity and safety of a split-virion, inactivated, trivalent influenza vaccine (Fluzone R) administered by intradermal and intramuscular route in healthy adults. Vaccine 2011;29(34):5666-74. doi: https://dx.doi.org/10.1016/j.vaccine.2011.06.010

31. Garg S, Thongcharoen P, Praphasiri P, et al. Randomized Controlled Trial to Compare Immunogenicity of Standard-Dose Intramuscular Versus Intradermal Trivalent Inactivated Influenza Vaccine in HIV-Infected Men Who Have Sex With Men in Bangkok, Thailand. Clin Infect Dis 2016;62(3):383-91. doi: https://dx.doi.org/10.1093/cid/civ884

32. Gorse GJ, Falsey AR, Johnson CM, et al. Safety and immunogenicity of revaccination with reduced dose intradermal and standard dose intramuscular influenza vaccines in adults 18-64 years of age. Vaccine 2013;31(50):6034-40. doi: https://dx.doi.org/10.1016/j.vaccine.2013.09.012

33. Han SH, Woo JH, Weber F, et al. Immunogenicity and safety of Intanza/IDflu intradermal influenza vaccine in South Korean adults : A multicenter, randomized trial. Human Vaccines and Immunotherapeutics 2013;9(9):1971-77. doi: http://dx.doi.org/10.4161/hv.25295

34. Hung IFN, Zhang AJ, To KKW, et al. Topical imiquimod before intradermal trivalent influenza vaccine for protection against heterologous non-vaccine and antigenically drifted viruses: A single-centre, double-blind, randomised, controlled phase $2 \mathrm{~b} / 3$ trial. Lancet Infect Dis 2016;16(2):209-18. doi: http://dx.doi.org/10.1016/S14733099\%2815\%2900354-0

35. Hung IF, Levin Y, To KK, et al. Dose sparing intradermal trivalent influenza (2010/2011) vaccination overcomes reduced immunogenicity of the $2009 \mathrm{H} 1 \mathrm{~N} 1$ strain. Vaccine 2012;30(45):6427-35. doi: https://dx.doi.org/10.1016/j.vaccine.2012.08.014

36. Hung IF, Zhang AJ, To KK, et al. Immunogenicity of intradermal trivalent influenza vaccine with topical imiquimod: a double blind randomized controlled trial. Clin Infect Dis 2014;59(9):1246-55. doi: https://dx.doi.org/10.1093/cid/ciu582

37. Leung DYM, Jepson B, Beck LA, et al. A clinical trial of intradermal and intramuscular seasonal influenza vaccination in patients with atopic dermatitis. J Allergy Clin Immunol 2017;139(5):1575-82.e8. doi: https://dx.doi.org/10.1016/j.jaci.2016.12.952

38. Nougarede N, Bisceglia $H$, Rozieres A, et al. Nine mug intradermal influenza vaccine and 15 mug intramuscular influenza vaccine induce similar cellular and humoral immune responses in adults. Hum Vaccin Immunother 2014;10(9):2713-20. doi: https://dx.doi.org/10.4161/hv.29695

39. Patel SM, Atmar RL, El Sahly HM, et al. A phase I evaluation of inactivated influenza $\mathrm{A} / \mathrm{H} 5 \mathrm{~N} 1$ vaccine administered by the intradermal or the intramuscular route. Vaccine 2010;28(17):3025-9. doi: https://dx.doi.org/10.1016/j.vaccine.2009.10.152

40. Seo YB, Choi WS, Lee J, et al. Comparison of the immunogenicity and safety of the conventional subunit, MF59-adjuvanted, and intradermal influenza vaccines in the elderly. Clin Vaccine Immunol 2014;21(7):989-96. doi: https://dx.doi.org/10.1128/CVI.00615-13

41. Song JY, Cheong HJ, Noh JY, et al. Long-term immunogenicity of the influenza vaccine at reduced intradermal and full intramuscular doses among healthy young adults. Clin 2013;2(2):115-9. doi: https://dx.doi.org/10.7774/cevr.2013.2.2.115 
medRxiv preprint doi: https://doi.org/10.1101/2020.10.06.20205989; this version posted October 8, 2020. The copyright holder for this preprint (which was not certified by peer review) is the author/funder, who has granted medRxiv a license to display the preprint in perpetuity. It is made available under a CC-BY-ND 4.0 International license .

42. Tsang P, Gorse GJ, Strout CB, et al. Immunogenicity and safety of Fluzone( R) intradermal and high-dose influenza vaccines in older adults $>=65$ years of age: a randomized, controlled, phase II trial. Vaccine 2014;32(21):2507-17. doi: https://dx.doi.org/10.1016/j.vaccine.2013.09.074

43. Van Damme P, Arnou R, Kafeja F, et al. Evaluation of non-inferiority of intradermal versus adjuvanted seasonal influenza vaccine using two serological techniques: a randomised comparative study. BMC Infect Dis 2010;10:134. doi: https://dx.doi.org/10.1186/14712334-10-134

44. Levin Y, Kochba E, Kenney R. Clinical evaluation of a novel microneedle device for intradermal delivery of an influenza vaccine: are all delivery methods the same? Vaccine 2014;32(34):4249-52. doi: https://dx.doi.org/10.1016/j.vaccine.2014.03.024

45. Levin Y, Kochba E, Shukarev G, et al. A phase 1, open-label, randomized study to compare the immunogenicity and safety of different administration routes and doses of virosomal influenza vaccine in elderly. Vaccine 2016;34(44):5262-72. doi: https://dx.doi.org/10.1016/j.vaccine.2016.09.008

46. Puig-Barbera J, Garcia-De-Lomas J, Diez-Domingo J, et al. Influenza vaccine effectiveness in preventing influenza $\mathrm{A}(\mathrm{H} 3 \mathrm{~N} 2)$-related hospitalizations in adults targeted for vaccination by type of vaccine: A hospital-based test-negative study, 2011-2012 A(H3N2) predominant influenza season, Valencia, Spain. PLoS ONE 2014;9(11) doi: http://dx.doi.org/10.1371/journal.pone.0112294

47. Marra F, Young F, Richardson K, et al. A meta-analysis of intradermal versus intramuscular influenza vaccines: immunogenicity and adverse events. Influenza other respi 2013;7(4):584-603. doi: https://dx.doi.org/10.1111/irv.12000

48. Pileggi $\mathrm{C}$, Lotito F, Bianco A, et al. Immunogenicity and safety of intradermal influenza vaccine in immunocompromized patients: a meta-analysis of randomized controlled trials. BMC Infect Dis 2015;15:427. doi: https://dx.doi.org/10.1186/s12879-0151161-z

49. Pileggi C, Mascaro V, Bianco A, et al. Immunogenicity and Safety of Intradermal Influenza Vaccine in the Elderly: A Meta-Analysis of Randomized Controlled Trials. Drugs Aging 2015;32(10):857-69. doi: https://dx.doi.org/10.1007/s40266-015-0303-8

50. Chen WH, Kozlovsky BF, Effros RB, et al. Vaccination in the elderly: an immunological perspective. Trends in immunology 2009;30(7):351-59.

51. Kunisaki KM, Janoff EN. Influenza in immunosuppressed populations: a review of infection frequency, morbidity, mortality, and vaccine responses. Lancet Infect Dis 2009;9(8):493504.

52. Eizenberg P, Booy R, Naser N, et al. Acceptance of Intanza ${ }^{\circledR} 9 \mu \mathrm{g}$ intradermal influenza vaccine in routine clinical practice in Australia and Argentina. Adv Ther 2011;28(8):640.

53. Reygrobellet C, Viala-Danten M, Meunier J, et al. Perception and acceptance of intradermal influenza vaccination: Patient reported outcomes from phase 3 clinical trials. Hum 2010;6(4):336-45. 